\title{
1 Power to Gas-Biomass oxycombustion hybrid system: Energy integration and potential applications
}

3

4

\author{
Manuel BAILERA ${ }^{\mathrm{a}}$, Pilar LISBONA ${ }^{\mathrm{b}}$, Luis M. ROMEO ${ }^{\mathrm{a}}$, Sergio ESPATOLERO ${ }^{\mathrm{a}}$ \\ ${ }^{a}$ Research Centre for Energy Resources and Consumption (CIRCE) - Universidad de Zaragoza, \\ CIRCE Building - Campus Río Ebro, Mariano Esquillor Gómez, 15, 50018 \\ Zaragoza, Spain \\ ${ }^{\mathrm{b}}$ Escuela Universitaria de Ingenierías Agrarias de Soria - Universidad de Valladolid, \\ Campus Universitario Duques de Soria, 42004, Soria, Spain.
}

\section{Abstract}

A promising hybridization which increases the chances of deployment of power to gas technology is found in the synergy with oxycombustion of biomass. This study assesses the efficiency of an energy integrated system under different sizes and potential applications. District heating and industrial processes are revealed as the most suitable potential applications for this hybrid technology. Global efficiency of the combined system may be increased through thermal energy integration. The relative increment of efficiency achieved for those designs which avoid the requirement of an air separation unit and for those which completely consumed the generated $\mathrm{CO}_{2}$, are $24.5 \%$ and $29.7 \%$ respectively. A 2 MWth district heating case study is also analysed, revealing that $81.2 \%$ of the total available heat from the PtG-oxy system could be integrated raising the global efficiency up to $78.7 \%$ at the adequate operational point. Further 'full-fuel-cycle' analysis will be required prior to decide the interest of the concept under a specific scenario in comparison to other available energy storage technologies.

\section{Keywords}

Power-to-Gas, Oxycombustion, Methanation, Oxyfuel, Integration 


\section{Introduction}

26 In the mid-term, one of the most promising energy storage technologies might be the Power to 27 Gas (PtG) process [1]. Strictly, renewable electricity is converted to fuel gas by means of electrolysis, storing electrical energy in form of hydrogen. Then, the generated $\mathrm{H}_{2}$ can be combined with carbon dioxide to produce methane through the Sabatier reaction [2].

$$
\mathrm{CO}_{2}+4 \mathrm{H}_{2} \leftrightarrow \mathrm{CH}_{4}+2 \mathrm{H}_{2} \mathrm{O} \quad \Delta \mathrm{H}_{298 \mathrm{~K}}=-165 \mathrm{~kJ} / \mathrm{mol}
$$

31 The availability of a suitable source of $\mathrm{CO}_{2}$ is the main limiting factor when assessing the 32 potential of Power to Gas deployment in a region; reducing considerably the geographic location possibilities for this technology [3]. Therefore, the access to a continued carbon dioxide flow to be fed to the PtG process becomes a crucial issue that must be properly addressed.

Biogas plants, waste managers, industries and power plants are the largest $\mathrm{CO}_{2}$ sources and the most interesting partners for integration with PtG [4]. Nevertheless, attention must be focused on the last two options since their efficiencies will be strongly penalized when the operation of carbon separation technology is accounted.

Biogas is mainly composed by methane (50 - $85 \%)$ and carbon dioxide (15 - 50 \%) [5], so a direct conversion of $\mathrm{CO}_{2}$ without previous separation is possible, avoiding the energy penalty associated to carbon capture. Due to this advantage, some of the major PtG projects in the world perform directly the methanation of the biogas (MeGa-store 4.7 MW [6], Erdgas Schwaben 1.0 MW [7], and P2G-BioCat 1.0 MW [8]). Similarly, waste management plants produce a gas mixture of $\mathrm{CH}_{4}$ and $\mathrm{CO}_{2}$, but it is usually burnt for self-consumption given its low quality [9]. Power plants and most industries generate $\mathrm{CO}_{2}$ during fuel combustion for electric or thermal energy production. However, carbon dioxide concentration in flue gas is low and capture costs up to $75 € / t_{\mathrm{CO} 2}$ depending on $\mathrm{CO}_{2}$ concentration [10]. Therefore, the hybridization of PtGOxycombustion is proposed as a method that avoids the capture penalty and allows the direct comparison between biogas upgrading and flue gas methanation. 
51 During oxycombustion, a mixture of recycled flue gas and pure oxygen is used as comburent 52 instead of air [11]. Thus, the large $\mathrm{N}_{2}$ content is substituted by the combustion products (mainly

$53 \mathrm{CO}_{2}$ and $\mathrm{H}_{2} \mathrm{O}$ ), and flue gas can achieve a high carbon dioxide concentration once steam is 54 condensed. Energy penalty associated to this capture process comes from the air separation unit 55 (ASU) that produces pure oxygen from air with a $190 \mathrm{kWh} / \mathrm{t}_{\mathrm{O} 2}$ average consumption [12]. 56 However, with an adequate size design of the PtG-Oxycombustion system, the by-produced 57 oxygen from electrolysis can replace the requirement of the ASU.

58 Furthermore, biomass has been selected as fuel for oxycombustion boiler to convert the process 59 into an entirely carbon neutral one. As the carbon dioxide used in the methanation process 60 comes from biomass combustion, the generated synthetic natural gas (SNG) will be equally 61 carbon neutral.

62 The scope of this study is to analyse the possible applications of hybrid PtG-Oxycombustion 63 systems depending of its size and operation conditions. Methanation process and $\mathrm{CO}_{2}$ 64 compression produce extra thermal energy that can be useful. The maximum potential 65 increment of the efficiency associated to complete integration of these heat streams is also 66 calculated.

67 Since the target of the work is to clarify what applications are feasible depending on the most suitable operation point for every size scale, the integrated system is characterized without

69 regarding any external loss that will penalize the profit of the concept. Prior to decide the 70 interest of the concept under a specific scenario in comparison to other available energy storage 71 technologies, further 'full-fuel-cycle' analysis should be performed.

\section{Hybrid system description}

The proposed configuration is a hybrid system which combines an oxyfuel boiler and a Power to Gas plant. A source of renewable energy supplies power to the electrolysers in the system (Figure 1) to store a constant amount of electricity in the form of hydrogen also co-producing oxygen. The oxygen generated in the electrolysers might be used to partially or completely 
cover the comburent demand in an oxyfuel boiler. In this way, the efficiency of this process is increased since the power consumption of the ASU would be reduced or even avoided. Additionally, methanation takes place between the $\mathrm{CO}_{2}$ contained in the flue gas from the oxyfuel thermal plant and the hydrogen from electrolysis to produce synthetic natural gas. If the flue gas is not completely consumed in methanation, the remaining can be directed to the compression train for transportation and storage.

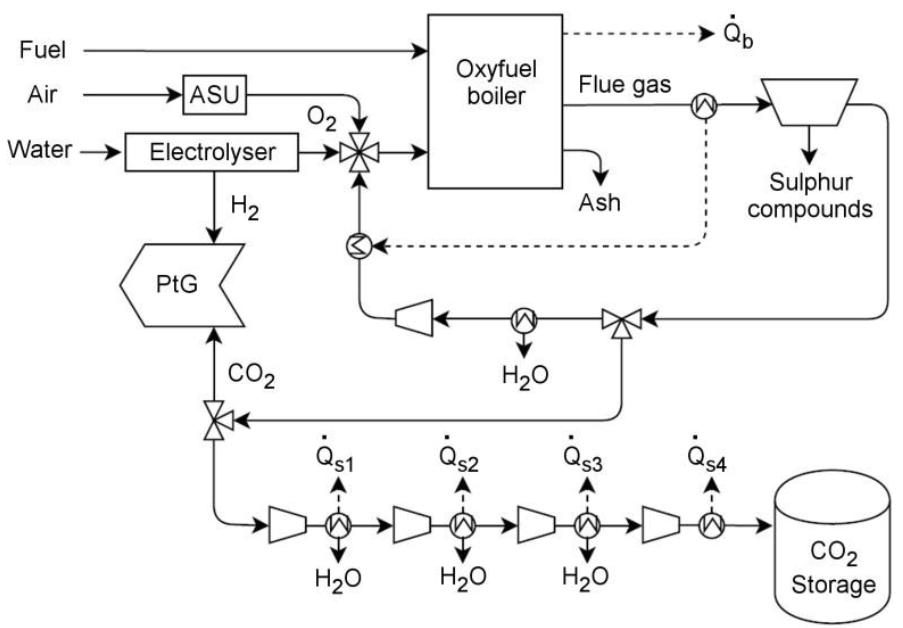

83

84 Figure 1. Block diagram of the hybrid power system.

85 In a prior study, the different operation ranges of the installation were obtained through simulation for a coal-fired oxyfuel boiler [13]. The analysis was performed by means of the definition of $\xi_{\text {oxy }}$, the ratio between the energy contained in hydrogen produced by electrolysis $\left(L H V_{H 2} \cdot \dot{m}_{H 2}\right)$ and the net thermal power generated by the oxyfuel boiler $\left(\dot{Q}_{b}\right)$ (Equation 2).

$$
\xi_{o x y}=\frac{L H V_{H 2} \cdot \dot{m}_{H 2}}{\dot{Q}_{b}}\left[\frac{k W_{H 2}}{k W_{t h}}\right]
$$

90 Coal was selected as input material since it represents the most extended fossil fuel for thermal energy supply in industry [14]. However, in order to achieve an entirely renewable system, it has been replaced by biomass (Table 1). The substitution of the fuel in the oxycombustion

93 boiler directly influences on the operation ranges since carbon, oxygen and water contents in the

94 fuel composition differ significantly. Furthermore, the use of biomass implies other technical 
risks that should be considered in the design of the installation such as structural changes in

96 flames that impose shorter particle sizes in biomass oxycombustion [15] or higher $\mathrm{H}_{2} \mathrm{O}$

97 concentrations inside the combustion chamber [16]. However, the study of these issues are

98 beyond the scope of this paper.

99 Table 1. Ultimate analysis of selected energy crop [w.b.] [17].

100

\begin{tabular}{|r|r|r|r|r|r|r|}
\hline $\mathrm{C}$ & $\mathrm{H}$ & $\mathrm{O}$ & $\mathrm{N}$ & $\mathrm{S}$ & $\mathrm{M}$ & $\mathrm{Z}$ \\
\hline 43.9 & 5.5 & 41.6 & 0.3 & 0.0 & 5.5 & 3.2 \\
\hline & Volatile Matter & Fixed Carbon & LHV [MJ $/ \mathrm{kg}]$ \\
\cline { 2 - 6 } & & & 17.3 & & \multicolumn{1}{c|}{17.8} \\
\hline
\end{tabular}

101 The entire hybrid system has been modelled in Aspen Plus ${ }^{\circledR}$ by combining and interconnecting

102 an oxyfuel boiler, a $\mathrm{CO}_{2}$ storing-compression train, an electrolyser and a methanation plant. The

103 oxyfuel boiler is assumed to operate with $15 \%$ of oxygen excess provided by three available

104 sources of $\mathrm{O}_{2}$, namely, ASU, electrolyser and recirculated flue gas.

105 The $\mathrm{CO}_{2}$ train consists of three compressors with pressure ratios of 3.5 and a fourth one with 106 pressure ratio of 3.0, achieving a final pressure of 91.9 bar. To improve the efficiency of 107 compressors, four intercoolers are installed between compression stages for recovering some

108 thermal energy which might be integrated. The temperature of the gas flow is reduced down to

$10940{ }^{\circ} \mathrm{C}$ in every stage, thus removing water too and providing a final high purity $\mathrm{CO}_{2}$ stream 110 (95.6\%-vol).

111 The electrolyser was modelled by programming a user-defined subroutine in Aspen Plus ${ }^{\circledR}$.

112 Based on literature, water conversion is above 99.9\% with an electrical consumption range from

1134.3 to $4.9 \mathrm{kWh} / \mathrm{Nm}^{3} \mathrm{H}_{2}$ and an operation temperature around $80{ }^{\circ} \mathrm{C}$ [18][19]. The influence of

114 the electrolyser efficiency in the overall performance of the hybrid plant was already studied in 
115 a previous work [13]. In this case, the consumption is set on $4.4 \mathrm{kWh} / \mathrm{Nm}^{3} \mathrm{H}_{2}\left(\eta_{\text {ele }, L H V}=\right.$

$11661.8 \%$ ) since it does not have any influence in the scope of the present study, the available heat

117 by-produced during the process.

118 Finally, methanation plant is designed to achieve a methane molar fraction above $95 \%$ in the

119 final SNG, which corresponds with the threshold concentration in Spanish legislation for 120 injection in the Natural Gas grid [20]. The proposed scheme, shown in Figure 2, is similar to the 121 original TREMP ${ }^{\mathrm{TM}}$ process of Haldor Topsøe [21]. It manages three adiabatic reactors at 30 bar 122 with an intermediate condensation stage and a recirculation over the first methanator.

123

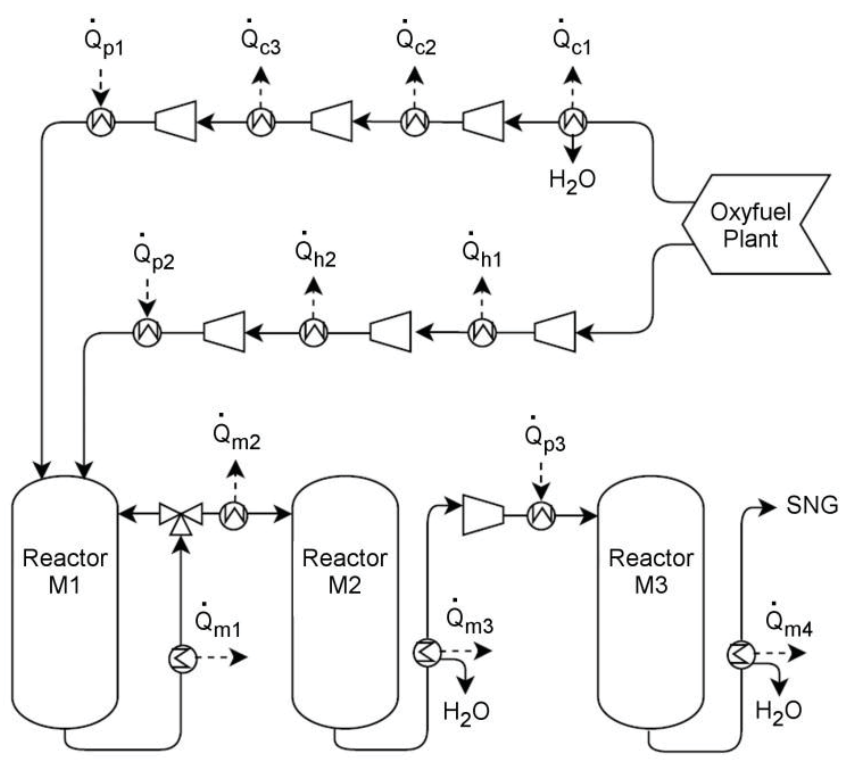

124 Figure 2. Methanation plant model in Aspen Plus ${ }^{\circledR}$.

125 To calculate the percentage of flue gas directed to methanation, $\phi_{F G M}$, two system conditions 126 must be taken into account. Firstly, a constant $\mathrm{H}_{2}: \mathrm{CO}_{2}$ molar ratio of 4 is set at the inlet of the 127 reactor M1 according to the stoichiometry of Equation 1. Then, the presence of oxygen entering 128 the methanator should be avoided since it would poison the catalysts [22]. Thus, it is consumed 129 by a controlled combustion with a small amount of the hydrogen from electrolysis. These two 130 conditions are used to derive Equation 3. The last parameter, $\dot{n}_{\mathrm{CO}_{2}, \text { Loss }}$, refers to the $\mathrm{CO}_{2}$ lost 
131 with water in the condensation stage prior the first reactor. Water is removed from the system

132 since a large presence of steam inhibits methanation reaction.

$$
\phi_{F G M}=100\left[\left(y_{\mathrm{CO}_{2}, \mathrm{FG}}+\frac{1}{2} y_{\mathrm{O}_{2}, \mathrm{FG}}\right)^{-1} \frac{\left(\dot{n}_{\mathrm{H}_{2}} / 4+\dot{n}_{\mathrm{CO}_{2}, \text { LOSS }}\right)}{\dot{n}_{\mathrm{FG}}}\right]
$$

134 Hydrogen and flue gas are passed through compression trains (30 bar) with intermediate cooling 135 stages down to $120{ }^{\circ} \mathrm{C}$ for heat recovering. A preheating stage up to $300{ }^{\circ} \mathrm{C}$ is also required 136 before the first methanator [23]. Then, the composition and temperature of outlet gas are 137 calculated at equilibrium state, minimizing Gibbs free energy in an adiabatic process.

138 Due to the loss of active surface area in the catalyst above $600{ }^{\circ} \mathrm{C}$ [24], the $80 \%$ of M1's outlet 139 have to be cooled $\left(300^{\circ} \mathrm{C}\right)$ and recirculated to maintain the process temperature around $550{ }^{\circ} \mathrm{C}$.

140 Thus, the exothermic energy of the Sabatier reaction can be easily recovered as high pressure 141 steam [25]. This thermal energy and the one from the intercooling stages of compression trains, 142 could be integrated at different temperatures (Table 2) improving the overall efficiency.

143 Then, temperature of the remaining stream is reduced to $250{ }^{\circ} \mathrm{C}$ before entering M2. Lower inlet 144 temperatures are typical in second and following methanators of commercial SNG processes 145 like TREMP ${ }^{\circledR}$ since they promote the upgrading of syngas [26]. Later, the steam content in the 146 outlet gas is partially condensed to avoid the inhibition of methanation reaction. However, an 147 excessively low steam molar fraction could generate solid carbon depositions [2]. In the studied 148 scheme, the third reactor will not produce solid carbon when the temperature of the intermediate 149 condensation stage remains above $125.5^{\circ} \mathrm{C}$, so temperature at this point is considered to be $150 \quad 130.0^{\circ} \mathrm{C}$.

151 The third reactor, M3, also operates without recirculation since high pressure favours methane

152 formation. Its inlet stream is preheated to $250{ }^{\circ} \mathrm{C}$ and the outlet gas is cooled down to $40{ }^{\circ} \mathrm{C}$ to 153 condense steam and reach a purity of methane over 95\%. 
155 The different subsystems in the hybrid plant present different cooling needs, from which 156 thermal energy can be recovered for integration purposes. Part of this cooling requirements 157 comes from the storage train in its condensation stages $\left(\dot{Q}_{s 1}, \dot{Q}_{s 2}, \dot{Q}_{s 3}\right.$ and $\left.\dot{Q}_{S 4}\right)$. Similarly, 158 thermal energy must be extracted from the intercoolers of the hydrogen $\left(\dot{Q}_{h 1}\right.$ and $\left.\dot{Q}_{h 2}\right)$ and flue 159 gas $\left(\dot{Q}_{c 1}, \dot{Q}_{c 2}\right.$ and $\left.\dot{Q}_{c 3}\right)$ compression trains. Lastly, in the methanation plant four more energy 160 streams are removed to mitigate the heat released by exothermic Sabatier reaction $\left(\dot{Q}_{m 1}, \dot{Q}_{m 2}\right.$, $161 \dot{Q}_{m 3}$ and $\left.\dot{Q}_{m 4}\right)$.

162 The available specific energy of each stream, defined as the total amount of thermal energy that must be removed to fulfil cooling requirements (Eq. (4)), is shown in Table 2.

$$
\dot{Q}_{j, i}=\dot{m}_{j, i} \cdot c p_{j, i} \cdot \Delta T_{j, i} \quad j=s, h, c, m ; \quad i=1,2, \ldots
$$

Depending on the source, heats are normalized with respect to different variables avoiding the influence of $\xi_{o x y}$. Compression heats are normalized with respect to the inlet mass flows, whilst methanation heat has been divided by the amount of hydrogen produced in the electrolyser. Thus, data of available thermal energy for external integration are valid for every $\xi_{\text {oxy }}$. It should be noted that values of available energy are not comparable for different sub-systems due to the distinct normalization.

Table 2. Available specific energies from $\mathrm{CO}_{2}$ compression $\left[\mathrm{kW}_{\mathrm{t}} /\left(\mathrm{t}_{\mathrm{CO} 2} / \mathrm{h}\right)\right]$, hydrogen compression $\left[\mathrm{kW}_{\mathrm{t}} /\left(\mathrm{t}_{\mathrm{H} 2} / \mathrm{h}\right)\right]$, flue gas compression $\left[\mathrm{kW}_{\mathrm{t}} /\left(\mathrm{t}_{\mathrm{CO} 2} / \mathrm{h}\right)\right]$ and methanation $\left[\mathrm{kW}_{\mathrm{t}} /\left(\mathrm{t}_{\mathrm{H} 2} / \mathrm{h}\right)\right]$.

\begin{tabular}{|l|l|l|l|r|}
\hline & $\begin{array}{l}\text { Stream } \\
\text { temperature } \\
{\left[{ }^{\circ} \mathrm{C}\right]}\end{array}$ & $\begin{array}{l}\text { Final } \\
\text { temperature } \\
{\left[{ }^{\circ} \mathrm{C}\right]}\end{array}$ & $\begin{array}{l}\text { Available } \\
\text { specific } \\
\text { energy }\end{array}$ & $\begin{array}{l}\text { Waste energy } \\
\text { in condensed } \\
\text { water* }\end{array}$ \\
\hline$\dot{Q}_{s 1}$ & 330.8 & 40.0 & 159.2 & 1.7 \\
\hline$\dot{Q}_{s 2}$ & 144.7 & 40.0 & 33.2 & 0.2 \\
\hline$\dot{Q}_{s 3}$ & 144.4 & 40.0 & 28.8 & 0.2 \\
\hline$\dot{Q}_{s 4}$ & 130.6 & 40.0 & 23.7 & - \\
\hline
\end{tabular}




\begin{tabular}{|l|r|r|r|r|}
\hline$\dot{Q}_{h 1}$ & 223.9 & 120.0 & 419.4 & - \\
\hline$\dot{Q}_{h 2}$ & 279.9 & 120.0 & 645.9 & - \\
\hline$\dot{Q}_{c 1}$ & 190.0 & 40.0 & 90.9 & 1.1 \\
\hline$\dot{Q}_{c 2}$ & 131.7 & 120.0 & 3.4 & - \\
\hline$\dot{Q}_{c 3}$ & 226.5 & 120.0 & 32.0 & - \\
\hline$\dot{Q}_{m 1}$ & 539.7 & 300.0 & 5826.8 & - \\
\hline$\dot{Q}_{m 2}$ & 300.0 & 250.0 & 224.7 & 498.8 \\
\hline$\dot{Q}_{m 3}$ & 380.4 & 130.0 & 3485.8 & 12.6 \\
\hline$\dot{Q}_{m 4}$ & 328.7 & 40.0 & 1052.4 & \\
\hline
\end{tabular}

* Energy content of condensed water in the cooling stage, reference $25^{\circ} \mathrm{C}$.

174 As shown in Table 2, there exist several lower limits for the final temperatures due to technical aspects. In the compression train for $\mathrm{CO}_{2}$ storage and the condensation stage prior the flue gas 176 compression to methanation, the temperature of condensers is set as $40{ }^{\circ} \mathrm{C}$ and the cooling 177 process can be carried out with water at ambient temperature. However, the intercooling phases 178 of hydrogen and flue gas compression are limited to $120^{\circ} \mathrm{C}$ since a subsequent preheating up to $179300{ }^{\circ} \mathrm{C}$ is required. In the methanation plant, $\dot{Q}_{m 1}$ and $\dot{Q}_{m 2}$ streams cannot be cooled below 300 $180{ }^{\circ} \mathrm{C}$ and $250{ }^{\circ} \mathrm{C}$ respectively, since they are introduced in the reactors and a minimum operating 181 temperature must be ensured. In addition, the heat removed in $\dot{Q}_{m 3}$ is limited since an excessive 182 steam condensation in this point will produce solid carbon deposition in the third methanator. 183 Therefore the minimum acceptable temperature for this intermediate condensation is $130{ }^{\circ} \mathrm{C}$.

184 Finally, $\dot{Q}_{m 4}$ belongs to a steam condensation stage, which is performed at $40^{\circ} \mathrm{C}$.

185 Despite all this available energy, only a fraction will be exchanged between hot streams and internal $\left(\dot{Q}_{p 1}, \dot{Q}_{p 2}\right.$ and $\left.\dot{Q}_{p 3}\right)$ or external cold streams due to these temperature limitations. In this study, the maximum energy recovery from integration will be defined as useful thermal energy. Furthermore, the waste energy contained in the condensed water that is extracted from the facility is calculated in reference to $25^{\circ} \mathrm{C}$ and also included in Table 2 . 


\section{Efficiency definition and potential improvement}

191 The efficiency of the system will be highly influenced by the operational variations that the

192 hybrid plant suffers through the increment of the ratio $\xi_{\text {oxy }}$. The key operation points for the

193 hybrid system depend on the fuel composition; they are calculated and shown in Figure 3 for an

194 oxyfuel boiler fed with biomass whose composition has been presented in Table 1.

195 Depending on the value of the ratio between boiler and electrolyser size, $\xi_{\text {oxy }}$, different 196 strategies of operation may be followed in the PtG-oxycombustion hybridized plant: (i) for a 197 given value, $\xi_{A S U}$, enough oxygen is produced in the electrolyzers to completely fed the 198 oxyfuel boiler and therefore ASU becomes unnecessary; and (ii) for $\xi_{\mathrm{CO} 2}$, the flue gas flow 199 produced in the oxyfuel combustion is completely reused and converted to SNG.

200

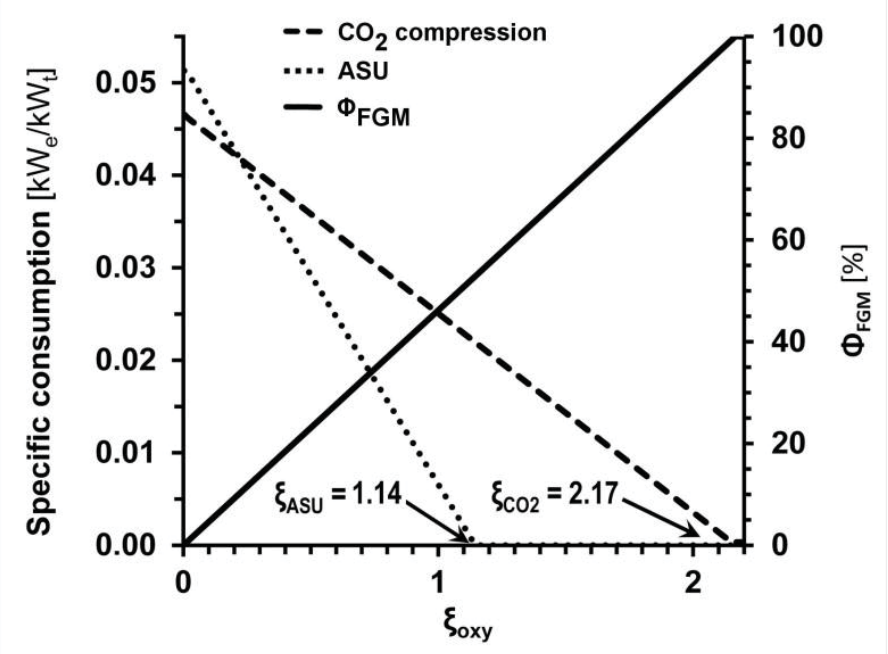

201 Figure 3. Specific consumptions and percentage of methanised flue gas vs $\xi_{\text {oxy }}$

202 The results from a previous study of the hybrid PtG-oxycombustion system fired by coal

203 showed the following size ratios for ASU elimination and total $\mathrm{CO}_{2}$ consumption: $\xi_{A S U}=1.33$

204 and $\xi_{\mathrm{CO} 2}=2.29$ [13]. The use of biomass in the boiler allows for reducing the size ratio 205 requirement which avoids the need of ASU since oxygen content in biomass is much greater 206 than in coal. In addition, given the smaller C:H ratio in biomass which limits the amount of 207 carbon dioxide generated in the boiler per $\mathrm{kW}_{\text {th }}$, the value of $\xi_{\text {oxy }}$ to convert entirely the flue 
gas is reduced. Nevertheless, those variation in characteristic size ratios as a function of fuel

209 type is beyond the scope of this paper and it is proposed as a further study.

210 The maximum efficiency of the hybrid system, once the additional available energy streams are

211 considered, can be written down as equation 5.

$$
\eta_{P t G+o x y}=\frac{\dot{Q}_{b}+L H V_{S N G} \dot{m}_{S N G}+\sum_{i=1}^{4} \dot{Q}_{s, i}+\sum_{i=1}^{2} \dot{Q}_{h, i}+\sum_{i=1}^{3} \dot{Q}_{c, i}+\sum_{i=1}^{4} \dot{Q}_{m, i}}{L H V_{f} \dot{m}_{f}+\dot{W}_{\text {aux }, o x y}+\dot{W}_{A S U}+\dot{W}_{C o m p}+\dot{W}_{\text {ele }}+\dot{W}_{\text {aux }, \text { meth }}}
$$

213 The global efficiency of the system accounts for the chemical energy contained in the synthetic

214 methane and the available heat from the boiler and other sources. In this first approach, the

215 entire available thermal energy from compression trains and methanation are considered useful

216 heat. Figure 4 illustrates the comparison between the global efficiency of a non-integrated

217 system and a system where complete use of the available heat is accomplished (Table 2). The

218 rest of possibilities, i.e. the partial use of the available heat due to exchanger temperature

219 limitations, will be intermediate curves. In addition, it should be noted that the electrolyser

220 consumption appears in Equation 5, so the final value of the overall efficiency is actually

221 influenced by the electrolyser performance. However, this effect was neglected since the gap between both limit situations behaves similarly in the possible range of electrolyser efficiency.

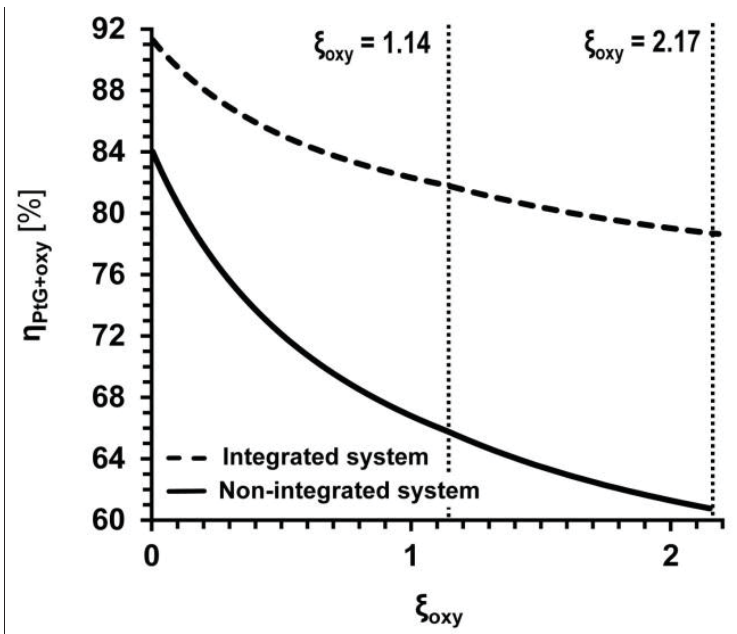

224 Figure 4. Hybrid plant efficiency vs $\xi_{\text {oxy }}$ (w and w/o energy integration) 
225 It is worthy to note that the system without Power to Gas $\left(\xi_{\text {oxy }}=0\right)$ still observes an 226 improvement in the global efficiency since the heat from the compression train could be 227 potentially integrated. As the share of PtG increases in the hybrid plant, overall efficiency 228 decreases since Power to Gas presents a more limited performance than the oxyfuel boiler. 229 However, the fall in efficiency is partially buffered thanks to the utilization of the waste energy 230 from different sources, mainly methanation heat.

231 The available heat from compression trains and methanation are grouped by source (Equation 6)

232 and presented in Figure 5 for illustrating their behaviour against $\xi_{o x y}$. Furthermore, all of them 233 have been normalized regarding the net thermal output of the boiler for direct comparison. It 234 must be highlighted the difference in order of magnitude between the methanation heat and the 235 other sub-systems.

$$
Q_{j}=\sum_{i} Q_{j, i} \quad j=s, h, c, m
$$

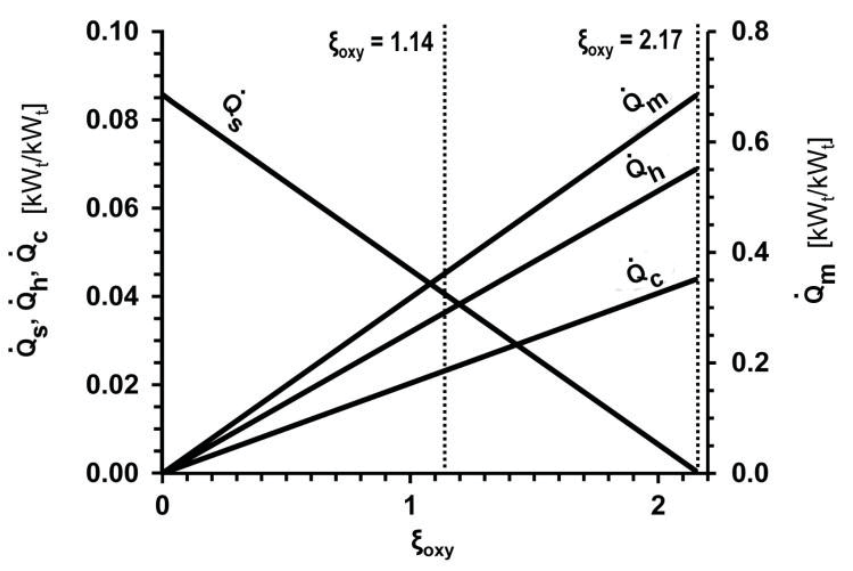

239 Figure 5. Available specific heats vs $\xi_{\text {oxy }}$

240 Data from Table 2 show how the ratio between $Q_{j, i}$ for a given $j$ is conserved with $\xi_{\text {oxy }}$. Thus,

241 it can be seen that the $55 \%$ of the methanation heat is always released in $\dot{Q}_{m 1}$ (Figure 6). 


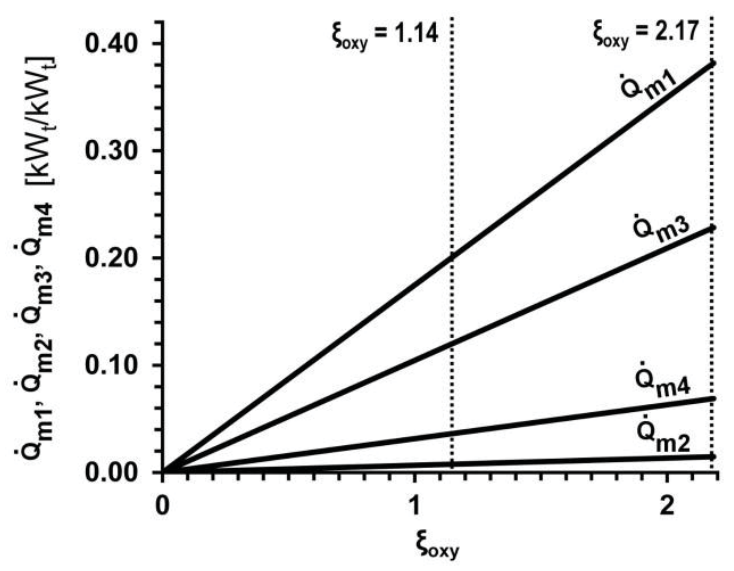

243 Figure 6. Available specific heats from methanators vs $\xi_{\text {oxy }}$

\section{Potential applications}

245 The final application of the PtG-oxy plant will define the adequate operation point, the required 246 equipment and its suitability. Five generic scales for the concept, based on literature, are 247 analysed to determine its technical and economic feasibility: households, district heating (DH), 248 industry, biomass power plants and co-firing (Table 3).

249 Table 3. Generic applications and characteristics for PtG-biomass oxycombustion at different 250 scales.

\begin{tabular}{|l|r|r|r|r|r|r|}
\hline Application & $\begin{array}{r}\text { Boiler } \\
\text { [MW] }\end{array}$ & $\xi_{\text {oxy }}$ & $\begin{array}{r}\text { Electrolyser } \\
{[\mathrm{MW}]}\end{array}$ & SNG [MW] & $\begin{array}{r}\text { Technical } \\
\text { feasibility }\end{array}$ & $\begin{array}{r}\text { Economic } \\
\text { feasibility }\end{array}$ \\
\hline Households & 0.01 & $\xi_{A S U}-1.15 \cdot \xi_{A S U}$ & 0.02 & 0.01 & $\checkmark$ & - \\
\hline $\begin{array}{l}\text { District } \\
\text { heating }\end{array}$ & 2 & $\xi_{A S U}-1.15 \cdot \xi_{A S U}$ & $3.4-3.9$ & $1.7-2.0$ & $\checkmark$ & $\checkmark$ \\
\hline Industry & 20 & $\xi_{A S U}-\xi_{C O 2}$ & $33.5-63.7$ & $16.8-31.9$ & $\checkmark$ & $\checkmark$ \\
\hline Power plant & 200 & $\xi_{A S U}-\xi_{C O 2}$ & $335-637$ & $168-319$ & - & $\checkmark$ \\
\hline Co-firing & 1000 & $0.8 \cdot \xi_{C O 2}-\xi_{C O 2}$ & $2549-3186$ & $1275-1593$ & - & $\checkmark$ \\
\hline
\end{tabular}

251 Note: Electrolyser efficiency 68.1\% (LHV)

252 Typical household heating consumption in a cold climate region is laid in the range $60-200$

$253 \mathrm{kWh} / \mathrm{m}^{2} / \mathrm{yr}$ [27]. Therefore, assuming 1500 hours of operation per year [28], a $150 \mathrm{kWh} / \mathrm{m}^{2} / \mathrm{yr}$

254 moderate specific consumption and a $90 \mathrm{~m}^{2}$ household, the required boiler power is around 10 $255 \mathrm{~kW}_{\mathrm{th}}$. 
256 District heating size distribution varies remarkably from one country to another. In Finland and

257 Denmark, which are northern Europe countries, majority of the DH systems are larger than 10

$258 \mathrm{MW}_{\text {th }}$ and rarely smaller than $2 \mathrm{MW}_{\text {th. }}$. Moreover, there exist a relevant number of $\mathrm{DH}$ facilities

259 with powers higher than $100 \mathrm{MW}_{\text {th. }}$ However, in Switzerland (central Europe) the district

260 heating systems are predominantly in the range $1-5 \mathrm{MW}_{\text {th }}$ with an important amount of plants

261 even smaller than $1 \mathrm{MW}_{\text {th }}$ [29]. Consequently, the percentage of citizens that have access to

262 district heating networks in the two first cases is $50 \%$ and $60 \%$ respectively, whilst in

263 Switzerland this share drops below 5 \% [30]. Nevertheless, heat-only boilers for district heating

264 are normally used as backup when peak demands are uncovered [31], so small sizes are more

265 suitable for this scope. Thus, a $2 \mathrm{MW}_{\text {th }}$ boiler size would be a representative size for a PtG-

266 biomass oxycombustion hybrid plant used in district heating.

267 Industry boiler applications and their average capacities can be summarized in five main fields:

268 chemicals (10.0 $\mathrm{MW}_{\text {th }}$ ), paper (31.4 $\mathrm{MW}_{\text {th }}$ ), food (5.9 $\mathrm{MW}_{\text {th }}$ ), refining (33.2 $\mathrm{MW}_{\text {th }}$ ) and metals

269 (9.2 $\mathrm{MW}_{\mathrm{th}}$ ), where typical sizes for each sector have been estimated from United States data

270 [32]. Thus, the average value for an industrial boiler for these five sectors would be around 18

$271 \mathrm{MW}_{\text {th }}$.

272 Direct combustion biomass plants are commercially available from a few $\mathrm{MW}_{\mathrm{e}}$ to $300 \mathrm{MW}_{\mathrm{e}}$,

273 and are the most common form of power generation with this renewable fuel $(90 \%$ of the

274 biomass used for energy purposes is combusted) [33]. Plants which are compatible with the

275 availability of local biomass feedstock are usually limited to $50 \mathrm{MW}_{\mathrm{e}}$, whilst those that are

276 supplied by internationally traded biomass may reach $300 \mathrm{MW}_{\mathrm{e}}$ [34]. A $50 \mathrm{MW}_{\mathrm{e}}$ power plant is

277 taken here as a generic case. Efficiency of biomass power plants in the $50 \mathrm{MW}_{\mathrm{e}}$ size range are

278 between $18 \%$ and $33 \%$ [34], so $26 \%$ efficiency is selected as a representative case. Hence, the

279 boiler power that this power plant would need is around $192 \mathrm{MW}_{\mathrm{th}}$.

280 In the co-firing case, the largest plant has a $4000 \mathrm{MW}_{\mathrm{e}}$ capacity (North Yorkshire, property of

281 Drax Power, 6x660 $\mathrm{MW}_{\mathrm{e}}$ ), whilst the following nine larger facilities have a total capacity in the 
283 between $10-1000 \mathrm{MW}_{\mathrm{e}}$, with a net electric efficiency between $35-42 \%$ [36]. Thus, the 284 chosen generic case is a $500 \mathrm{MW}_{\text {e }}$ plant with an intermediate efficiency value (38.5 \%), which would need a $1.3 \mathrm{GW}_{\text {th }}$ boiler.

The selection of operation point must be in accordance to the scale of the plant and its final purpose. Hence, small scale installations (households and DH) are not compelled to capture

288 their emissions since the amount of produced $\mathrm{CO}_{2}$ will not be large enough. Thus, an operation

289 point around $\xi_{A S U}$ would be recommended. In medium and large scale facilities, such as 290 industrial applications or power plants, to avoid greenhouse gas emissions might be mandatory 291 and economically interesting. However, these applications could be operated in a wider range between $\xi_{A S U}$ and $\xi_{\mathrm{CO} 2}$ without restrictions given the neutrality in $\mathrm{CO}_{2}$ emissions of biomass combustion. Contrary, co-firing facilities cannot take advantage of biomass neutral emissions, and they will be compelled to capture their carbon dioxide. Therefore, a range next to $\xi_{\mathrm{CO} 2}$ would be the most suitable operation for those applications (Figure 7).

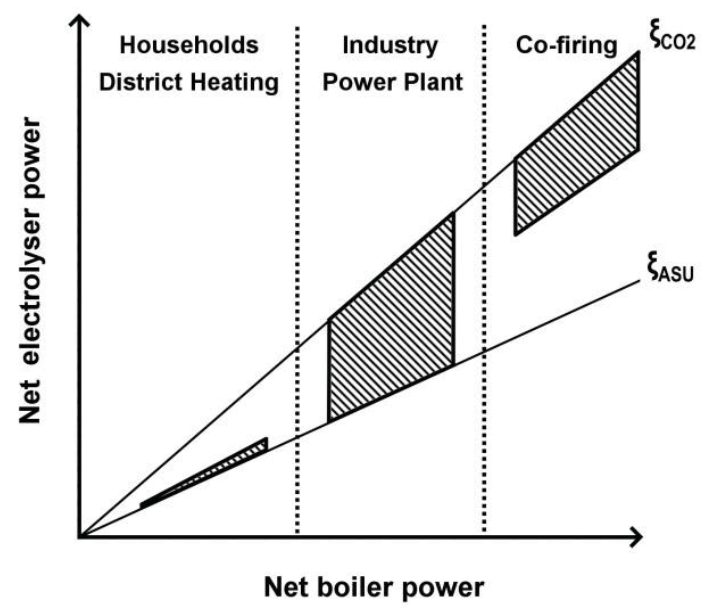

Figure 7. Map of operation points for different scale facilities

298 Once the adequate range of electrolyser size is fixed for each scale, the technical feasibility is 299 determined by the state of the art of the electrolysis technology. Nowadays, electrolysers are 
300 commercially available from a few $\mathrm{kW}_{\mathrm{e}}$ up to $2 \mathrm{MW}_{\mathrm{e}}$ [37]. Therefore, it may be considered that

301 there is no lower limit but an upper one, which implies that industrial uses are the largest

302 possible applications through the combination of fifteen to thirty units of $2 \mathrm{MW}_{\mathrm{e}}$ size

303 electrolysers. Hence, the next scale steps (power plants and co-firing), would require more than

304160 of these electrolysers, so it is assumed that there is not any technical feasibility in these

305 cases.

306 Finally, the economic feasibility is assessed as a function of the SNG production capacity taken

307 from the results presented in the final report of the TKI power-to-gas system analysis project 308 developed in Rozenburg (Figure 8) [38].

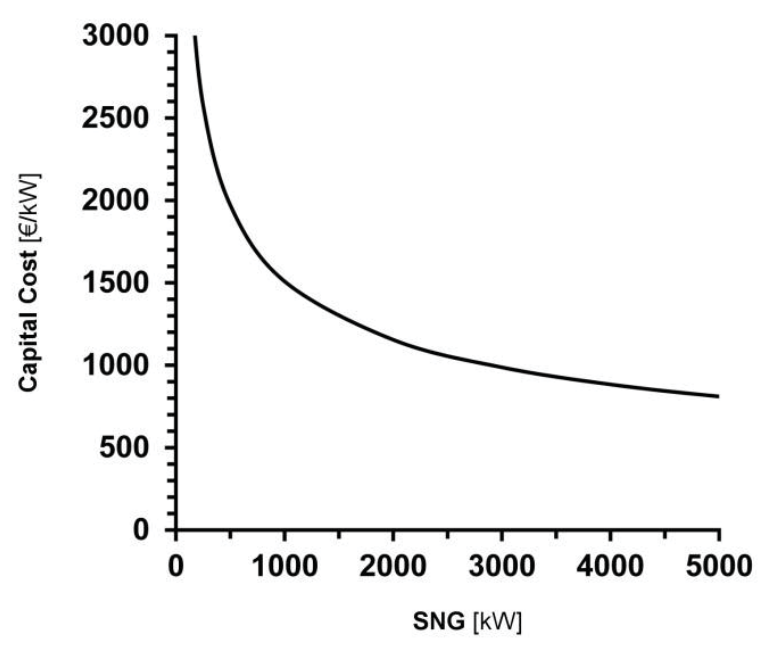

309

$310 \quad$ Figure 8. Capital cost for methanation plants [38]

311 The amount of SNG generated under each potential application is calculated using the

312 efficiency obtained through Aspen Plus simulations ( $\left.\eta_{P t G} \cong 50 \%\right)$. From these calculations it

313 is obtained that the application in households of the PtG-oxy hybrid system would present

314 unbearable capital and operational costs while for larger scales these costs are strongly

315 attenuated.

316 In conclusion, under current conditions only district heating and industry applications seem to

317 be technically and economically feasible for a PtG-biomass oxycombustion hybrid plant. 
318 Therefore, these both cases are briefly analysed in the two following sections. However, with a

319 mature PtG technology and a greater electrolyser development, smaller and larger applications

320 could be also suitable.

\subsection{District heating}

322

Heating and domestic hot water (DHW) necessities in residential buildings account for $75 \%$ of

323 their total energy consumption [39]. A study performed by Carpio et al. [40] shows that the

324 replacement of diesel with biomass, in Spanish residential building heating, leads to $\mathrm{CO}_{2}$ emission reductions between $82.9 \%$ and $95.3 \%$, whilst whether natural gas is replaced, emissions would drop between $77.4 \%$ and $93.7 \%$. The proposal of a PtG-biomass oxyfuel boiler for district heating is, thus, well justified.

In 2014, the concept of $4^{\text {th }}$ Generation District Heating (4GDH) was defined. Its main advantage is the increment in efficiency due to the lower distribution temperatures (30 - $\left.70{ }^{\circ} \mathrm{C}\right)$ [41].

330 Several 4GDH projects funded by the IEA-DHC research programme have been finalized and 331 other new four projects will be executed during the 2014-2017 period [42]. However, given the fact that the 4GDH approach is still under research, the technical parameters accounted in this study are based on previous district heating generations.

334 The $3^{\text {rd }}$ Generation DH systems usually are operated at end costumer supply temperatures

335 between $80-100{ }^{\circ} \mathrm{C}$ [43], and pressures above 6 bar [44]. However, hot water transportation

336 from DH plants to end user distribution network is made by transmission networks whose

337 design parameters are more robust. The rigid plastic jacket pipes are the most widely used (140

$338{ }^{\circ} \mathrm{C}$ and 25 bar) because of their greater standardization and lower prices [29], so these characteristics are chosen for the present case study.

340 The waste heat from PtG-biomass oxycombustion plant is recovered in a series of exchangers

341 with a minimum difference of $20^{\circ} \mathrm{C}$ between cold and hot streams. Therefore, the lower limit

342 temperature to cool down the hot streams is $160{ }^{\circ} \mathrm{C}$. Under this situation, $\dot{Q}_{m 1}$ and $\dot{Q}_{m 2}$ will be 
343 exhausted, $\dot{Q}_{s 2}, \dot{Q}_{s 3}, \dot{Q}_{s 4}$ and $\dot{Q}_{c 2}$ cannot be used, and the remaining heats will be only partially

344 recovered. The useful energy that can be extracted from each point and the amount of water

345 heated to $140{ }^{\circ} \mathrm{C}$ and 25 bar are shown in Table 4.

346 Table 4. Percentage of available specific heat (Table 2) that is useful in DH systems, and data 347 for the generic case (2 $\mathrm{MW}_{\text {th }}$ at $\xi_{A S U}$, Table 3).

\begin{tabular}{|l|r|r|r|}
\hline & Useful specific heat & Useful heat & Produced hot-water \\
& {$[\%]$} & {$[\mathrm{kW}]$} & {$[\mathrm{kg} / \mathrm{h}]$} \\
\hline$\dot{Q}_{s 1}$ & 37.5 & 19.7 & 118.0 \\
\hline$\dot{Q}_{s 2}$ & 0.0 & 0.0 & 0.0 \\
\hline$\dot{Q}_{s 3}$ & 0.0 & 0.0 & 0.0 \\
\hline$\dot{Q}_{s 4}$ & 0.0 & 0.0 & 0.0 \\
\hline$\dot{Q}_{h 1}$ & 61.5 & 17.7 & 106.1 \\
\hline$\dot{Q}_{h 2}$ & 75.0 & 33.3 & 199.5 \\
\hline$\dot{Q}_{c 1}$ & 11.1 & 3.7 & 22.2 \\
\hline$\dot{Q}_{c 2}$ & 0.0 & 0.0 & 0.0 \\
\hline$\dot{Q}_{c 3}$ & 63.3 & 7.5 & 44.9 \\
\hline$\dot{Q}_{m 1}$ & 100.0 & 399.9 & 2396.3 \\
\hline$\dot{Q}_{m 2}$ & 100.0 & 15.4 & 92.3 \\
\hline$\dot{Q}_{m 3}$ & 93.9 & 224.5 & 1345.2 \\
\hline$\dot{Q}_{m 4}$ & 43.3 & 31.3 & 187.6 \\
\hline Total & 81.2 & 753.0 & 4512.1 \\
\hline
\end{tabular}

349 Given the limited amount of GHG emissions in district heating systems, to install a capture and

350 compression facility for the $\mathrm{CO}_{2}$ is not mandatory. Therefore, the heat recovered from the

351 compression train may compute or not when calculating the efficiency of the system. In Figure

3529 the efficiencies under both scenarios together with the lower and upper limits of the base case

353 (Figure 4) are represented. 
354

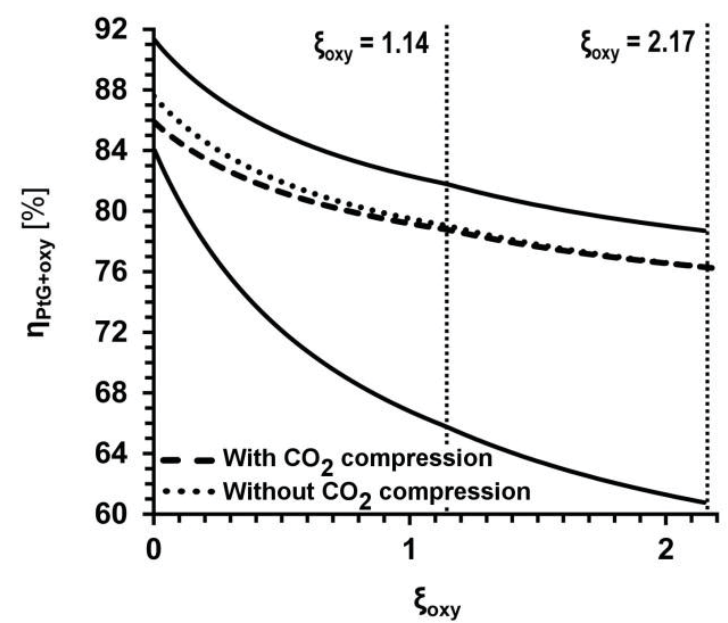

355 Figure 9. Hybrid plant efficiency vs $\xi_{\text {oxy }}$ (DH application)

356 Initially, the inclusion of a $\mathrm{CO}_{2}$ compression stage in the integrated system implies a reduction

357 in the efficiency. However, once the ASU becomes unnecessary this penalty disappears and

358 both systems have barely the same efficiency, because the greater influence of the PtG process

359 against the compression heat.

360 5.2. Industry

361 Contrary to district heating application where the target of the produced heat is clear and its

362 technical requirements are fixed, industry applications might be oriented to different final uses

363 in a large range of temperatures. Therefore, a general analysis of industry applications similar to

364 the DH analysis cannot be performed. Nevertheless, some aspects of these potential applications

365 can be highlighted.

366 Pulp and paper manufacturers, as well as chemical industry, are two of the main medium

367 temperature steam consumers that could take advantage of PtG-oxyfuel systems, since chemical

368 industry employ $47 \%$ of their entire energy expenditure for producing steam and paper industry

369 up to $84 \%$ [45]. Furthermore, paper manufacturing generates bark and sawdust as by-product

370 that is commonly used as biofuel for producing steam that is self-consumed [46]. Hence, paper

371 mills are one of the best candidates for a big scale PtG-biomass oxycombustion development. 
372 As a summary, some of the main potential uses included in the paper industry and chemical

373 sector, are shown in Table 5, with their corresponding requirements of temperature and 374 pressure.

375 Table 5. Requirements for some of the potential uses of steam in paper and chemical industries $376[45][47][48]$.

\begin{tabular}{|l|r|r|}
\hline & & $\mathrm{P}_{\text {Steam }}[\mathrm{bar}]$ \\
\hline Paper industry & & \\
\hline Digesting & 170.0 & 7.9 \\
\hline Chemical recovery & 144.4 & 3.1 \\
\hline Bleaching & 126.7 & 1.4 \\
\hline Drying & 126.7 & 1.4 \\
\hline Chemical industry* & & 1.0 \\
\hline Distillation & 121.1 & 11.0 \\
\hline Drying & 187.8 & 1.0 \\
\hline Blending & 121.1 & 3.5 \\
\hline Melt compounding & 146.1 & \\
\hline *PVC production case & &
\end{tabular}

378 The strong differences between steam requirements in a specific process together with the

379 availability of multiple thermal energy flows coming from the PtG-Oxycombustion boiler, 380 suggest the utilization of the pinch analysis technique for maximizing the overall net efficiency.

381 There exists huge potential for integration between industry and the proposed hybrid technique and the possibility of greater development through further specific studies.

384 A PtG-Oxycombustion hybrid system which transforms electricity from renewable sources and 385 heat from biomass combustion into carbon-neutral synthetic natural gas has been proposed and analysed. In the light of results, the most adequate applications in which this system could be integrated have also been assessed. 
388 Small scale plants are urged to operate near above $\xi_{A S U}$ since lower $\mathrm{CO}_{2}$ emissions are normally

389 not compelled to be captured through economic penalties, while for large scale facilities is

390 recommended to operate with size ratios next to $\xi_{\mathrm{CO} 2}$ to ensure the complete conversion of flue

391 gas flow into SNG. Hence, when technical and economic feasibilities of generic cases are

392 evaluated taking into account these assumptions (Table 3), the most suitable applications for the

393 PtG-Oxycombustion hybrid system are found.

394 The required size for the electrolyser size in the cases of power plants and co-firing applications

395 would be too large to be technically feasible, whilst the thermal energy consumption of

396 household are so small that specific cost of the required plant matching the demand would be

397 extremely high. However, district heating and industrial applications requirements lie in an

398 affordable range for the hybrid system.

399 In addition, extra thermal energy production from methanation and compression trains is

400 quantified to assess the potential increment of global efficiency for these applications. At the

401 operational point $\xi_{A S U}$, heat integration allows to increase overall net efficiency from $65.7 \%$ to

$40281.8 \%$, whilst for $\xi_{\mathrm{CO} 2}$ from $60.7 \%$ to $78.7 \%$.

403 The analysis of a district heating case shows that a $81.2 \%$ of the available heat becomes useful

404 for integration at the recommended operational point $\xi_{A S U}$, so overall net efficiency is increased

405 up to $78.7 \%$. If temperature requirements were lower, as in 4GDH systems, useful heat and

406 efficiency would be even greater.

407 Further studies are proposed in order to analyse the influence of the type of fuel used in the

408 boiler. First results indicates that oxygen content and $\mathrm{C}: \mathrm{H}$ ratio produce remarkable

409 modifications in the values of $\xi_{\mathrm{ASU}}$ and $\xi_{\mathrm{CO} 2}$, respectively.

410 Lastly, the boundaries of the system should be extended in order to perform a 'full-fuel-cycle'

411 analysis of the proposed concepts and to estimate the emission factors and losses associated 
412 with the power generation. This analysis would allow a realistic assessment of the concept

413 under a specific scenario in comparison to other available energy storage technologies.

\section{Acknowledgements}

415 The authors would like to acknowledge funding from Fundación Iberdrola through the program

416 “Ayudas a la Investigación en Energía y Medioambiente” 2014 - 2015.

417 Abbreviations

$\begin{array}{ll}\text { 4GDH } & 4^{\text {th }} \text { generation district heating } \\ \text { ASU } & \text { Air separation unit } \\ \text { DH } & \text { District heating } \\ \text { DHW } & \text { Domestic hot-water } \\ \text { LHV } & \text { Lower heating value } \\ \text { M } & \text { Moisture } \\ \text { M1 } & \text { Methanator } 1 \\ \text { M2 } & \text { Methanator } 2 \\ \text { M3 } & \text { Methanator } 3 \\ \text { PtG } & \text { Power to Gas } \\ \text { SNG } & \text { Synthetic natural gas } \\ \text { Z } & \text { Ash }\end{array}$

418

419 Nomenclature

\section{Variables}

$c p$

LHV

$\dot{m}$

$\dot{n}$

$P$

$\dot{Q}$

$T$

$\dot{W}$

$y$

$\eta$

$\xi_{A S U}$

$\xi_{\mathrm{CO} 2}$

$\xi_{\text {oxy }}$

$\phi_{F G M}$

\section{Subscripts}

$A S U$

aux
Specific heat at constant pressure $[\mathrm{kJ} / \mathrm{kg} \cdot \mathrm{K}]$

Lower heating value $[\mathrm{kJ} / \mathrm{kg}]$

Mass flow [kg/s]

Molar flow [kmol/s]

Pressure [bar]

Thermal power [kWt]

Temperature [K]

Electric power [kWe]

Molar fraction [-]

Efficiency [\%]

Minimum required ratio between electrolyser power and boiler net output to avoid ASU necessity [kWe/kWt]

Minimum required ratio between electrolyser power and boiler net output to consume flue gas completely [kWe/kWt]

Ratio between electrolyser power and boiler net output [kWe/kWt]

Percentage of flue gas directed to methanation [\%]

Air separation unit

Auxiliary consumption 


$\begin{array}{ll}b & \text { Boiler } \\ \mathrm{CO}_{2} & \text { Carbon dioxide } \\ \mathrm{comp} & \mathrm{CO}_{2} \text { compression } \\ e & \text { Electric } \\ e l e & \text { Electrolyser } \\ f & \text { Fuel } \\ \mathrm{FG} & \text { Flue gas } \\ \mathrm{H}_{2} & \text { Hydrogen } \\ \text { Loss } & \text { Losses in condensation phase prior M3 } \\ M & \text { Methanator } \\ \text { meth } & \text { Methanation } \\ \mathrm{O}_{2} & \text { Oxygen } \\ \text { oxy } & \text { Oxyfuel plant } \\ P t G & \text { Power to Gas } \\ P t G+\text { oxy } & \text { Power to Gas-Oxyfuel hybrid system } \\ S N G & \text { Synthetic natural gas } \\ t h & \text { Thermal }\end{array}$

420

\section{References}

422

[1] Vandewalle J, Bruninx K, D'haeseleer W. Effects of large-scale power to gas conversion on the power, gas and carbon sectors and their interactions. Energy Convers Manag 2015;94:28-39. doi:10.1016/j.enconman.2015.01.038.

[2] Gao J, Wang Y, Ping Y, Hu D, Xu G, Gu F, et al. A thermodynamic analysis of methanation reactions of carbon oxides for the production of synthetic natural gas. RSC Adv 2012;2:2358. doi:10.1039/c2ra00632d.

[3] Schneider L, Kötter E. The geographic potential of Power-to-Gas in a German model region - Trier-Amprion 5. J Energy Storage 2015;1:1-6. doi:10.1016/j.est.2015.03.001.

[4] Sterner M. Bioenergy and renewable power methane in integrated 100\% renewable energy systems (Thesis). Kassel University Press GmbH, 2009. ISBN 978-3-89958-7982.

[5] Thrän D, Billing E, Persson T, Svensson M, Daniel-Gromke J, Ponitka J, et al. Biomethane, Status and Factors Affecting Market Development and Trade. IEA Bioenergy, 2014. ISBN 978-1-910154-10-6.

[6] Iskov H, Rasmussen N. Global screening of projects and technologies for Power-to-Gas and Bio-SNG. Project Report. Danish Gas Technology Centre, 2013. ISBN 978-877795-373-6.

[7] Kirchmayr M. Power-to-Gas: Modellierung der Energieverwertungspfade und Einflussnahme einer veränderten Strommarktsituation. Diplomica Verlag GmbH; 2014. ISBN 3842893914.

[8] Denmark turns excess wind power into gas via Hydrogenics tech. Fuel Cells Bull 2014;2014:8-9. doi:10.1016/S1464-2859(14)70082-3. 
[9] Szwaja S, Kovacs VB, Bereczky A, Penninger A. Sewage sludge producer gas enriched with methane as a fuel to a spark ignited engine. Fuel Process Technol 2013;110:160-6. doi:10.1016/j.fuproc.2012.12.008.

[10] Persson T, Murphy J, Jannasch A-K, Ahern E, Liebetrau J, Trommler M, et al. A perspective on the potential role of biogas in smart energy grids. IEA Bioenergy, 2014. ISBN 978-1-910154-12-0.

[11] Wall T, Liu Y, Spero C, Elliott L, Khare S, Rathnam R, et al. An overview on oxyfuel coal combustion-State of the art research and technology development. Chem Eng Res Des 2009;87:1003-16. doi:10.1016/j.cherd.2009.02.005.

[12] Hu Y, Li X, Li H, Yan J. Peak and off-peak operations of the air separation unit in oxycoal combustion power generation systems. Appl Energy 2013;112:747-54. doi:10.1016/j.apenergy.2012.12.001.

[13] Bailera M, Lisbona P, Romeo LM. Power to gas-oxyfuel boiler hybrid systems. Int J Hydrogen Energy 2015. doi:10.1016/j.ijhydene.2015.06.074.

[14] Eisentraut A, Brown A. Heating without global warming - Market developments and policy considerations for renewable heat. International Energy Agency, Paris, 2014.

[15] Holtmeyer ML, Kumfer BM, Axelbaum RL. Effects of biomass particle size during cofiring under air-fired and oxyfuel conditions. Appl Energy 2012;93:606-13. doi:10.1016/j.apenergy.2011.11.042.

[16] Jurado N, Darabkhani HG, Anthony EJ, Oakey JE. Oxy-combustion Studies Into the Co -Firing of Coal and Biomass Blends: Effects on Heat Transfer, Gas and Ash Compositions. Energy Procedia 2014;63:440-52. doi:10.1016/j.egypro.2014.11.047.

[17] Pickard SC, Daood SS, Pourkashanian M, Nimmo W. Co-firing coal with biomass in oxygen- and carbon dioxide-enriched atmospheres for CCS applications. Fuel 2014;137:185-92. doi:10.1016/j.fuel.2014.07.078.

[18] Tijani AS, Yusup NAB, Rahim a. HA. Mathematical Modelling and Simulation Analysis of Advanced Alkaline Electrolyzer System for Hydrogen Production. Procedia Technol 2014;15:799-807. doi:10.1016/j.protcy.2014.09.053.

[19] Dieguez P, Ursua a, Sanchis P, Sopena C, Guelbenzu E, Gandia L. Thermal performance of a commercial alkaline water electrolyzer: Experimental study and mathematical modeling. Int J Hydrogen Energy 2008;33:7338-54. doi:10.1016/j.ijhydene.2008.09.051.

[20] BOE-A-2013-185. Resolución de 21 de diciembre de 2012, de la Dirección General de Política Energética y Minas, por la que se modifica el protocolo de detalle PD-01. Ministerio de Industria, Energía y Turismo; 2013.

[21] Kopyscinski J, Schildhauer TJ, Biollaz SM a. Production of synthetic natural gas (SNG) from coal and dry biomass - A technology review from 1950 to 2009. Fuel 2010;89:1763-83. doi:10.1016/j.fuel.2010.01.027. 
[22] Agersborg J, Lingehed E. Integration of Power-to-Gas in Gasendal and GoBiGas. Master's Thesis Report No. T2013-396. Chalmers University of Technology, 2013.

[23] Nguyen TTM, Wissing L, Skjøth-Rasmussen MS. High temperature methanation: Catalyst considerations. Catal Today 2013;215:233-8. doi:10.1016/j.cattod.2013.03.035.

[24] Rostrup-Nielsen JR, Pedersen K, Sehested J. High temperature methanation. Sintering and structure sensitivity. Appl Catal A Gen 2007;330:134-8. doi:10.1016/j.apcata.2007.07.015.

[25] Sudiro M, Bertucco a. Synthetic Natural Gas (SNG) from coal and biomass: a survey of existing process technologies, open issues and perspectives. Nat Gas 2010:105-27. doi:10.5772/9835.

[26] Heyne S, Seemann MC, Harvey S. Integration study for alternative methanation technologies for the production of synthetic natural gas from gasified biomass. Chem Eng Trans 2010;21:409-14. doi:10.3303/CET1021069.

[27] Edenhofer O, Pichs-Madruga R, Sokona Y, Farahani E, Kadner S, Seyboth K, Adler A, Baum I, Brunner S, Eickemeier P, Kriemann B, Savolainen J, Schlömer S, Stechow C, Zwickel T, Minx JC. Climate Change 2014: Mitigation of Climate Change. Contribution of Working Group III to the Fifth Assessment Report of the Intergovernmental Panel on Climate Change. IPCC, 2014. ISBN 978-1-107-05821-7.

[28] IDAE. Guía técnica de instalaciones de biomasa térmica en edificios. Instituto para la Diversificación y Ahorro de la Energía, 2009. ISBN 978-84-96680-46-3.

[29] Nussbaumer T, Thalmann S. Status Report on District Heating Systems in IEA Countries. Swiss Federal Office of Energy, 2014. ISBN 3-908705-28-2.

[30] Colmenar-Santos A, Rosales-Asensio E, Borge-Diez D, Mur-Pérez F. Cogeneration and district heating networks: Measures to remove institutional and financial barriers that restrict their joint use in the EU-28. Energy 2015;85. doi:10.1016/j.energy.2015.03.088.

[31] United Nations Environment Programme. District Energy in Cities - Unlocking the Potential of Energy Efficiency and Renewable Energy. 2015.

[32] Energy Technology Systems Analysis Programme. Industrial Combustion Boilers. Techonology Brief I01-May. International Energy Agency-ETSAP, 2010.

[33] IRENA. Biomass for Power Generation, In: Renewable Energy Technologies: Cost Analysis Series, Vol. 1: Power Sector, Issue 1/5. International Renewable Energy Agency, 2012.

[34] Eisentraut A, Brown A. Technology Roadmap - Bioenergy for Heat and Power. International Energy Agency, IEA Renewable Energy Division, 2012. ISBN 9789264123236.

[35] Vakkilainen E, Kuparinen K, Heinimö J. Large Industrial Users of Energy Biomass Report for IEA Bioenergy Task 40. Lappeenranta University of Technology, 2013. 
533

534

535

536

537

538

539

540

541

542

543

544

545

546

547

548

549

550

551

552

553

[36] Lempp P. Biomass Co- firing. Techonology Brief E21 - January. International Energy Agency-Energy Technology Systems Analysis Programme (IEA-ETSAP), and International Renewable Energy Agency (IRENA), 2013.

[37] Sharma S, Ghoshal SK. Hydrogen the future transportation fuel: From production to applications. Renew Sustain Energy Rev 2015;43:1151-8. doi:10.1016/j.rser.2014.11.093.

[38] Grond L, Schulze P, Holstein J. Systems Analyses Power to Gas - Deliverable 1: Technology Review. Final Report - Project TKIG01038. KEMA Nederland B.V., 2013.

[39] Sharif MKA, Al-abidi a a, Mat S, Sopian K, Ruslan MH. Review of the application of phase change material for heating and domestic hot water systems. Renew Sustain Energy Rev 2015;42:557-68. doi:10.1016/j.rser.2014.09.034.

[40] Carpio M, Zamorano M, Costa M. Impact of using biomass boilers on the energy rating and CO2 emissions of Iberian Peninsula residential buildings. Energy Build 2013;66:732-44. doi:10.1016/j.enbuild.2013.07.079.

[41] Lund H, Werner S, Wiltshire R, Svendsen S, Thorsen JE, Hvelplund F, et al. 4th Generation District Heating (4GDH). Integrating smart thermal grids into future sustainable energy systems. Energy 2014;68:1-11. doi:10.1016/j.energy.2014.02.089.

[42] IEA-DHC. Annex XI 2014-2017. Bringing countries together to research, innovate and grow district heating and cooling - including CHP. International Energy Agency, 2014.

[43] Dalla A, Li H, Svendsen S, Werner S, Persson U, Rehling K. Annex X Final report. Toward 4th Generation District Heating : Experience and Potential of Low-Temperature District Heating. International Energy Agency - DHC, 2014.

[44] Energy Technology Systems Analysis Programme. District Heating. Techonology Brief E16 - January. International Energy Agency-ETSAP, 2013.

[45] U.S. Department of Energy. Steam System Opportunity Assessment for the Pulp and Paper, Chemical Manufacturing, and Petroleum Refining Industries. 2002. doi:DOE/GO102002-1639.

[46] Isaksson J, Åsblad A, Berntsson T. Influence of dryer type on the performance of a biomass gasification combined cycle co-located with an integrated pulp and paper mill. Biomass and Bioenergy 2013;59:336-47. doi:10.1016/j.biombioe.2013.10.002.

[47] ATECYR. Guía técnica de agua caliente sanitaria central. Instituto para la Diversificación y Ahorro de la Energía, 2010. ISBN 978-84-96680-52-4.

[48] IDAE. Guía práctica sobre instalaciones centralizadas de calefacción y agua caliente sanitaria (ACS) en edificios de viviendas. Información y consejos para las comunidades de vecinos. Instituto para la Diversificación y Ahorro de la Energía, 2008. 